УДК 373.5:2(44)

\begin{abstract}
Інна Лаухіна,
кандидат педагогічних наук, дочент кафедри теорії та практики іноземних мов Уманського державного педагогічного

університету імені Павла Тичини

Ольга Побережсник,

стариий викладач кафедри теорії та практики іноземних мов Уманського державного педагогічного університету імені Павла Тичини
\end{abstract}

Таміла Філіппович, викладач кафедри теорії та практики іноземних мов Уманського державного педагогічного університету імені Павла Тичини

\title{
ЗАГАЛЬНІ МЕТОДИЧНІ ПІДХОДИ ДО РЕАЛІЗАЦІЇ ОСВІТНЬОГО АСПЕКТУ ЗНАНЬ ПРО РЕЛІГІЇ ТА ЇХНЬОГО ВИХОВНОГО ПОТЕНЦАЛУ У СУЧАСНИХ ШКОЛАХ ФРАНЦЇ̈
}

У статті йдеться про можливості запровадження у зміст національної шкільної освіти Франції знань про релігї, розглядається проблема поєднання світських принципів сучасної освіти та реалізації релігієзнавчого компонента (блоків знань про релігію) до навчальних програм франиузької загальноосвітньої школи, виокремлено основні методичні підходи до впровадження релігієзнавчих знань, які є найбільш оптимальними при викладанні школярам знань про релігію, проаналізовано зміст релігієзнавчого компонента в державних икільних програмах початкової та середньої иколи (колежі та лічеї) Франції.

Аналіз змісту початкової освіти у Франції показав, що релігієзнавчі знання застосовуються в них незначною мірою і здебільшого імплічитно. Так, на уроках франиузької мови $і$ літератури навчальний матеріал відповідного змісту використовується для того, щоб полегшити учням засвоєння певних висловів, які стосуються релігії.

Визначено, що у франиузьких колежах та лічеях надається перевага основним методичним прийомам, які $\epsilon$ найбільш оптимальними при викладанні школярам знань про релігію. Блоки знань релігієзнавчого змісту містяться в навчальних програмах з історії мистечтва, історії, географії, філософії, франиузької мови і літератури. Їх розміщено концентрично, з поступальним нарощенням складності, з урахуванням міжпредметних 
зв'язків і крос дисциплінарної взаємодоповнюваності. Автори навчальних програм рекомендують учителям під час викладання відповідних рубрик $i$ тем програми використовувати історичні документи, мапи, твори мистечтва, а також Біблійні тексти.

Аналіз навчальних програм засвідчив, що зміст релігієзнавчих блоків знань перебуває на експериментальній стадії: з'являються авторські програми, деякі з них можна назвати інноваційними. Згідно з позицією багатьох франиузьких дослідників, запровадження релігієзнавчого компонента в навчальні програми носить обмежений характер, невирішеними залишаються питання щодо порівняльної методики вивчення релігій.

Ключові слова: блоки знань про релігію, релігієзнавчий компонент, зміст навчальних дисциплін загальноосвітніх середніх икіл, основні методичні підходи реалізаиії знань про релігії.

The article describes the ability of providing the knowledge about religion into the content of national school education in France. The problem of connecting the secular principles of modern education and the realization of religious components (areas of knowledge about religion) to the curriculum of French secondary school is raised. The main methodological approaches to the providing of religious knowledge are defined. They are the most optimal when conducting religion at school. The content of religious component in state school curriculum for primary and secondary schools in France is analyzed. The main circumstances of providing religious components in school curriculum are defined. The author emphasizes the limited character of knowledge about religion in French schools and a limited theoretical basis of investigating religious factors and features.

The article describes the ability of providing certain areas of knowledge about religion implicitly being included into the content of national school education in France. So, educational material with correspondent content can be used during the French classes to help students in learning particular expressions, concerning religion.

The usage of this item is much more effective at the history classes.

The content of religions component is widely used being included to the curriculum of the majority of colleges and lyceums in France. Knowledge of definite content, combined in blocks, is included into the studying programme of different subjects, especially history of arts, history, geography, philosophy, language and literature of France.

They are located concentrically with the progressive increase of complexity, considering interdisciplinary connections and the complementarity of subjects with the help of each.

The authors of studying programs give their recommendations to use 
historical documents, maps, masterpieces (paintings, architecture, sculpture, literature, music) and biblical texts while teaching within the limits of certain topics and rubrics.

At the present stage the implementation of the religious component is realized into the content of state secondary education in France in rather dynamical and innovational manner.

Key words: areas of knowledge about religion, religious component, content of curriculum in comprehensive secondary schools, main methodological approaches to realization of knowledge about religion, circumstances of providing religious components, school curriculum.

У кінці XX - на початку XXI ст. у країнах Європи, зокрема у Франції, розпочався процес зближення церкви й держави, який зумовив перегляд освітніх програм та уведення до їх змісту релігієзнавчого компонента (блоків знань про релігію). 3 огляду на це грунтовного розгляду потребує питання щодо методики викладання знань про релігію у французьких загальноосвітніх школах, що визначило актуальність нашої наукової розвідки.

Мета роботи - розглянути методичні підходи до реалізації релігієзнавчого компонента, застосування його освітнього та виховного потенціалу у змісті навчальних дисциплін колежів та ліцеїв Франції. Це питання стало об'єктом вивчення французьких науковців М. Cереса, Р. Нуайя, Ж. Жоншере, Ф. Одіж’є, Ж.-П. Віллема та ін.

Розроблення і впровадження релігієзнавчого компонента знань у шкільні навчальні програми розпочалося лише наприкінці XX ст. Поштовхом для цього став 1982 рік, коли Ліга французьких освітян на Генеральній асамблеї в Монпельє порушила питання щодо поліпшення інформування учнів середньої школи про релігійні явища і проблеми, а також про доповнення програм середньої школи відповідними змістовими блоками. Із самого початку релігієзнавчий компонент став розвиватися як блок знань про релігію, що входить до змісту низки шкільних предметів (історія мистецтв, історія, географія, громадянознавство, філософія, французька мова і література), а також як кросдисциплінарний складник навчальних програм для французьких колежів і ліцеїв. Ця тенденція зберігається й нині.

Упровадження релігієзнавчого компонента у французьких колежах та ліцеях потребує педагогічно виваженого і науково обгрунтованого методичного супроводу. У преамбулі до колективної монографії «Викладати історію релігій у колежі та ліцеї. 24 навчальних модулі» (1999) ii автори Рене Нуайя та Жан Жоншере зазначають, що врахування «релігійної культури» у межах загальноосвітніх навчальних програм стосується, насамперед, виховної місії школи. Йдеться про необхідність 
допомогти молоді шкільного віку краще зрозуміти життя людей на основі моральних i етичних цінностей. Релігійна культура спонукає до визначення власного «я», формування поведінки стосовно інших i навколишнього світу: наприклад, навчитися жити, розрізнюючи різні релігії та релігійні концепції в атмосфері толерантності, а не байдужості, на засадах плюралізму й автономності власних суджень. Саме це французький учений, філософ Мішель Серес називає «світським дивом», яке полягає в умінні відчути себе на місці іншого і набути знань «з іншого боку» $[13$, с. 7$]$.

Ураховуючи те, що знання про релігії мають не стільки освітній, скільки виховний характер, французькі науковці Рене Нуайя та Жан Жоншере визначили декілька методичних підходів щодо впровадження релігієзнавчого компонента у французьку загальну освіту. У нашій статті ми керуємося визначенням методичного підходу, наданому українським науковцем Семеном Устимовичем Гончаренком. Під методичним підходом ми розуміємо виділення головного в педагогічному явищі [1].

Французькі науковці Рене Нуайя та Жан Жоншере у праці «Викладати релігію у колежі та ліцеї. 24 навчальних модулі» («Enseigner les religions au collège et au lycée. 24 séquences pédagogiques», 1999) визначили методичні підходи щодо впровадження релігієзнавчого компонента у французьку загальну середню освіту: використання педагогічного досвіду католицької освіти, урахування особливостей кожного навчального предмета і застосування між предметних зв'язків [5].

Для вивчення релігієзнавчих тем можна використовувати проект виховної дії, у якому Рене Нуайя виділяс чотири етапи: 1) вибір теми і визначення цілей; 2) презентація теми; 3) формування навичок вести дискусію через розвиток інтересу і зацікавленості проектом та через розвиток критичного мислення; 4) оцінювання набутих навичок 3 урахуванням успіхів і труднощів учнів [10].

Сучасні французькі освітні програми для колежів і ліцеїв, крім змісту, містять рекомендації щодо методів, які необхідно застосовувати при викладанні того чи іншого предмета. Отже, самі програми $\epsilon$ нормативними документами 3 методичного супроводу, однак вони передбачають і педагогічну творчість учителя, який може використовувати загальні методичні підходи. Для реалізації релігієзнавчого компонента використовуються методи, притаманні кожній дисципліні.

Специфіка предмета «Історія та географія» полягає у тісних міждисциплінарних зв'язках (з французькою мовою і літературою, «Наукою про життя і Землю», громадянознавством), умінні працювати 3 документальними джерелами та картами. Це зумовлює застосування таких методичних підходів, як міжпредметний, порівняльно-історичний, полікультурний, національної ідентичності, кросдисциплінарний, 
компетентнісний, діяльнісний.

Міжпредметний підхід полягає у вивченні кроспредметних тем, що увійшли до програм з французької мови і літератури та історії для 6 класу колежу: Старий та Новий Заповіт, «Одіссея» Гомера та «Енеїда» Вергілія. Опрацювання теми «Зародження юдаїзму» у 6 класі колежу опирається на уривки з Біблії (розповідь про створення світу, Авраама та його нащадків, об'єднане царство Давида та Соломона). При вивчені теми «Зародження християнства» передбачено, що учні зможуть пояснити основні положення християнського віровчення з опертям на розділи Нового Заповіту [11].

Навчальний предмет «Історія та географія» пов'язаний 3 громадянською освітою. Так, у програмах для колежу, - робить наголос французька дослідниця Франсуаза Одіж'є, - розглядаються питання щодо етнічної, національної та релігійної ідентичності, проблеми громадянства тощо [9].

При викладанні географії застосовують міжпредметний і діяльнісний (копіювання або створення) підходи. Особливість «Географії» полягає в тому, що вона $\epsilon$ i природничим, і гуманітарним предметом, оскільки ознайомлює учнів 3 природою Землі, расами і народами, економічним розвитком країн світу, а також формує загальну культуру школярів [7]. Міжпредметний підхід при вивченні географії можна спостерігати при опрацюванні кроспредметної теми «Дерева». Дерева характеризують клімат певного регіону (географія); дерево $є$ частиною живої природи (біологія); дерево згадується у творах письменників (французька література); образ дерева можна передати через твори мистецтва (історія мистецтв); складання генеалогічного дерева відтворює родинні зв'язки або приналежність до певної нації чи віросповідання (громадянознавство). За висловом французького соціолога Даніеля Ерве-Леже, «віряни складають одну релігійну групу, одне дерево, яке відбруньковує різні гілки, але зберігає традиційну віру та неперервний зв'язок усіх нащадків» [14, с. 153-171].

У французьких школах особлива увага приділяється застосуванню карт та опануванню їх мовою, оскільки карти та зображення, на думку вчителів, $\epsilon$ найважливішими педагогічними засобами у реалізації навчальних програм історії та географії. Відтак широко практикуються копіювання або створення карт, виконання нескладних зображень об' єктів, наприклад нанесення на карту історичних місць, що згадуються у Біблії, позначення територій, на яких поширювалося християнство тощо. У методичних порадах зазначається, що такий діяльнісний підхід до вивчення предмета буде ефективним для тих учнів, у яких переважає візуальний спосіб мислення. Оскільки вивчення документальних та картографічних джерел $\epsilon$ обов'язковим компонентом програми, досягнення учнів у цих видах навчальної діяльності підлягає окремому контролю та оцінюванню [12]. 
У програмах із «Громадянознавства» для колежів і ліцеїв наголошується на тому, що громадянська освіта покликана підготувати молодь до активної суспільної діяльності і компетентного громадянства. Громадянознавча освіта у Франції реалізується у процесі викладання багатьох навчальних дисциплін. Так, на уроках історії у колежі учні розглядають права та обов'язки громадян у їх історичній ретроспективі, учителі предмета «Наука про життя і Землю» формують громадянські позиції учнів щодо охорони і збереження довкілля тощо [8, с. 38-39].

Реалізація релігієзнавчого компонента на уроках громадянознавства відбувається через засвоєння учнями таких понять, як рівність, братерство, безпека, свобода, справедливість, плюралізм. Наприклад, учні 5 класу колежів розглядають питання боротьби 3 будь-якими проявами дискримінації, у тому числі через релігійну приналежність, у 4 класі колежу права людини вивчаються у нерозривній єдності 3 фундаментальними свободами. На думку інспектора національної освіти Домінік Борн, виважене поєднання громадянської та релігійної освіти покликане розвивати інтерес учнів до питань релігійної культури, кращого розуміння ними сучасного світу, виховувати толерантність до представників інших конфесій [3, с. 32-33].

Одним із основних підходів, які використовують учителі на уроках громадянознавства, $\epsilon$ пізнавальний, що реалізується через бесіду, лекцію, дискусію. Аргументовані дискусії з питань, що торкаються релігійного життя людини, надають учням можливість не тільки мобілізувати знання 3 різних навчальних дисциплін - історії, філософії, літератури, географії, економічних і соціальних наук, - але й формують навички культури полеміки. Французькі педагоги вважають, що дискусії повинні грунтуватися на принципах «поваги до інших і виключати будь-яку авторитарну форму інтелектуальної або ідеологічної диктатури», тому звертається увага на вміння слухати аргументи опонентів та об'єктивно оцінювати їхню точку зору. У ході дискусій рекомендують використовувати проблемний підхід, що передбачає самостійне опрацювання учнями різноманітних джерел - текстів літературних творів або юридичних документів, використання матеріалів засобів масової інформації, фото- і відеоматеріалів. Серед форм роботи із засвоєння релігієзнавчих тем широко використовуються мозковий штурм, дидактичні (рольові) ігри [2].

Предмет «Історія» є одним із провідних у коледжах та ліцеях Франції, оскільки має не тільки пізнавальну цінність, а й покликаний сприяти взаєморозумінню між людьми з різними культурними, етнічними, лінгвістичними та релігійними традиціями, допомагає учневі усвідомити себе представником певної країни та регіону, громадянином Європи i світу. Вивчення історії виробляє у школярів уміння установлювати 
просторово-часові зв'язки, що формує у них логічне мислення, здатність зіставляти історичні події, робити висновки, узагальнювати історичні факти. Автори програм з історії рекомендують застосовувати на уроках порівняльно-історичний, культурно-історичний, полікультурний, плюралістичний підходи [6].

На сучасному етапі релігієзнавчий компонент упроваджується в зміст загальної середньої освіти Франції досить динамічно і інноваційно. Цьому сприяє розроблення низки авторських програм, які частково або в повному обсязі можуть використовуватися у шкільних курсах за вибором. Наприклад, до загальноосвітніх програм 3 історії авторські розробки пропонують французькі науковці Н. Альє, А. ван ден Керхове, А. М.-К. Люльє та П. Левек.

На уроках філософії французькі вчителі застосовують порівняльноісторичний, порівняльно-зіставний, міжпредметний, проблемний, полікультурний підходи. Практикуються поточні письмові роботи та усні доповіді, дискусії з основних тем програми, що вказує на широке використання дослідницького підходу. Найбільш ефективними формами контролю та оцінки знань учнів $є$ дослідження, творчі роботи та пояснення тексту. Такі види самостійної роботи ліцеїстів виявляють їх розуміння проблеми, що розглядається, здатність оперувати відповідною термінологією, володіння прийомами аргументації [4].

Французька мова вивчається в усіх класах основної і старшої школи. Учні колежів опановують знання 3 таких розділів мовознавства, як граматика, орфографія і лексика. Велика увага звертається на формування навичок виразного читання та вміння писати творчі роботи. Ліцеїсти поглиблюють і вдосконалюють знання мови шляхом читання та аналізу художніх творів. Тут можна простежити міжпредметні зв'язки, оскільки учні знайомляться із творами французького класицизму (Расіна, Корнеля, Мольєра, Лафонтена) не тільки на уроках мови, але й французької літератури, філософії, а уривки 3 творів грецьких і римських авторів (Гомера, Есхіла, Еврипіда, Софокла, Платона, Плутарха, Тацита, Овідія, Горація) вивчаються в курсах стародавніх мов. У програмах 3 «Французької мови» у терміналі L i ES ліцейської освіти школярам пропонують вивчати Біблію, основні тексти грецької і латинської Античності [9].

Вивчення літератури у ліцеях грунтується на історичних $\mathrm{i}$ культурних традиціях Франції, на утвердженні загальнолюдських цінностей засобами художнього твору. Викладання літератури здійснюється у єдності з мистецьким контекстом та історичною епохою, у яких створювався літературний текст, а також за допомогою міжпредметних зв'язків (історія, географія, музика, громадянознавство). Основним методом вивчення художнього твору $є$ «пояснення тексту» 
(explication du texte), тобто детальний аналіз невеликого твору або уривку [9].

Вивчення предмета «Історія мистецтв» потребує використання експонуючого методу навчання, при якому школярі не тільки пізнають дійсність через твори мистецтва, але й «пропускають» іï через власні почуття, оцінюють відповідно до своїх життєвих цілей та ідеалів.

Різновидом експонуючого підходу $\epsilon$ імпресивний метод, який реалізується через участь школярів у такій навчальній діяльності, яка викликає глибокі переживання, прагнення обмінюватися враженнями, бажання змінювати себе відповідно до соціальних, моральних, естетичних цінностей суспільства. Практикуються зустрічі учнів з діячами мистецтв, екскурсії до музеїв, відвідування виставок та майстерень художників $[15$, c. $45-46]$.

Отже, реалізація релігієзнавчих знань в основній та старшій школі здійснюється за допомогою таких методичних підходів, як міжпредметний, порівняльно-історичний, полікультурний, кросдисциплінарний, культурноісторичний, плюралістичний, експонуючий, пізнавальний, діяльнісний, дослідницький, проблемний, компетентнісний, національної ідентичності, a також їх комплексного комбінування та варіативного поєднання у авторських методиках. Застосовуються також так звані метапідходи, які охоплюють усі навчальні дисципліни, але учитель, ураховуючи специфіку і логіку кожного предмета, може обирати найбільш ефективні з них. Попри це, провідні французькі вчені наразі акцентують увагу на дещо обмеженому характері запровадження знаннь про религії у французьких школах, на недостатній теоретичній базі досліджень й тлумачень релігійних фактів та явищ, перспективними и невирішеними залишаються питання, які пов'язані із порівняльною методикою вивчення религій, тому работа в цьому напрямі $\epsilon$ переспективною для подальших наукових розвідок.

\section{СПИСОК ВИКОРИСТАНИХ ДЖЕРЕЛ}

1. Український педагогічний словник / [укл. С. У. Гончаренко]. - К. : Либідь, 1997. - 376 с.

2. Audigier Françoise. L'éducation civique dans l'école française [Electronic resource] / Françoise Audigier. - URL : http://www.eduscol.education.fr/ DO126/religion_modernite.pdf.

3. Borne Dominique. Enseigner la dimention historique des religions à l'école laïque / Dominique Borne // Cahiers pédagogiques. - Avril, 1994. № 323. - P. 32-33.

4. Gaudin Philippe. Enseignement de la philosophie en terminal et fait religieux / Philippe Gaudin. - IESR - Institut européen en sciences des religions, mis à jour le: 29/05/2007 [Electronic resource]. - URL : 
http://www.iesr. ephe.sorbonne.fr/index3764.html.

5. Joncheray Jean, Nouailhat René. Enseigner les religions au collège et au lycée. 24 séquences pédagogiques / Joncheray Jean, Nouailhat René. Paris: Les Éditions de l'Atelier - 1999. - 195 p.

6. Kerchove Anna van den. Cinq remarques préalables (Nouveau programme d'histoire de sixième (rentrée 2009) [Electronic resource] / Anna van den Kerchove. - IESR, mis à jour le: 20/02/2009. - URL : http://www.iesr. ephe.sorbonne.fr/index5551.html.

7. Laithier Stéphanie. Le fait religieux dans des nouveaux programmes (Histoire-Geographie-Education Civique) de lycée professionnel / Stéphanie Laithier. - IESR - Institut européen en sciences des religions, mis à jour le: 20/02/2009. - URL : http://www.iesr.ephe.sorbonne.fr/ index5551.html. - Назва з екрана.

8. L'Huillier Marie-Claude. Des Dieux, des hommes et de la société. Enseigner les religions de l'Antiquité en sixième / Marie-Claude L'Huillier, Pierre Leveque // Cahiers pédagogiques. - Avril, 1994. № 323. - P. 38-39.

9. Martini Evelyne. Enseignement de Lettre et fait religieux, IESR - Institut européen en sciences des religions / Evelyne Martini. - 17/02/2009. URL : http://www.iesr.ephe.sorbonne.fr/index5495.html. - Назва з екрана.

10. Nouailhat René. Le fait religieux dans l'enseignement / René Nouailhat. Chemins de formation, Magnard, 2002. - $128 \mathrm{p}$.

11. Nouveau programme d'histoire de sixième (rentrée 2009), IESR. 20/02/2009. - URL : http://www.iesr.ephe.sorbonne.fr/index5551.html.

12. Qu'apprend-on au collège? Cahier des exigences pour le collégien. Ministère de l'éducation nationale. Conseil national des programmes. Paris : CNDP/XO Editions, 2002. - $180 \mathrm{p}$.

13. Serres Michel. Pourquoi et comment / Michel Serres. - Le Monde de l'éducation. - 1990. - № 270. - P. 7.

14. Willaime J.-P. Identité religieuse en Europe / Jean-Paul Willaime, HervieuLeger Daniel, Davide Grace. - Paris : La Découverte 1996. - P. 153-171.

15. Zarhartchouk Jean-Michel. Vous entrez dans la cathédrale...et dans la mosquée / Jean-Michel Zarhartchouk // Cahiers pédagogiques. - № 323. Avril, 1994. - P. 45-46. 